\title{
LONG-TERM PERFORMANCE OF PAVEMENT STRUCTURES WITH COLD IN-PLACE RECYCLED BASE COURSE
}

\section{AUDRIUS VAITKUS ${ }^{1}$, JUDITA GRAŽULYTE் ${ }^{1 *}$, ANDRIUS BALTRUŠAITIS ${ }^{2}$, JURGITA ŽIDANAVIČIŪTE்', DONATAS ČYGAS ${ }^{2}$ \\ ${ }^{1}$ Road Research Institute, Vilnius Gediminas Technical University, Vilnius, Lithuania \\ ${ }^{2}$ Dept of Roads, Vilnius Gediminas Technical University, Vilnius, Lithuania}

Received 15 October 2020; accepted 12 December 2020

\begin{abstract}
Properly designed and maintained asphalt pavements operate for ten to twenty-five years and have to be rehabilitated after that period. Cold in-place recycling has priority over all other rehabilitation methods since it is done without preheating and transportation of reclaimed asphalt pavement. Multiple researches on the performance of cold recycled mixtures have been done; however, it is unclear how the entire pavement structure (cold recycled asphalt pavement overlaid with asphalt mixture) performs depending on binding agents. The main objective of this research was to evaluate the performance of cold in-place recycled asphalt pavements considering binding agents (foamed bitumen in combination with cement or only cement) and figure out which binder leads to the best pavement performance. Three
\end{abstract}

* Corresponding author. E-mail: judita.grazulyte@vgtu.lt

Audrius VAITKUS (ORCID ID 0000-0001-5103-9747)

Judita GRAŽULYTÉ (ORCID ID 0000-0001-6502-9400)

Andrius BALTRUŠAITIS (ORCID ID 0000-0002-4144-8579)

Jurgita ŽIDANAVIČIŪTÉ (ORCID ID 0000-0002-6371-3097)

Donatas ČYGAS (ORCID ID 0000-0001-5789-1981)

Copyright (C) 2021 The Author(s). Published by RTU Press

This is an Open Access article distributed under the terms of the Creative Commons Attribution License (http://creativecommons.org/licenses/by/4.0/), which permits unrestricted use,

distribution, and reproduction in any medium, provided the original author and source are credited. 
road sections rehabilitated in 2000, 2003, and 2005 were analysed. The performance of the entire pavement structure was evaluated in terms of the International Roughness Index, rut depth, and pavement surface distress in 2013 and 2017.

Keywords: cold in-place recycling (CIR), cold recycled asphalt pavement, International Roughness Index (IRI), pavement surface distress, reclaimed asphalt pavement (RAP), rut depth.

\section{Introduction}

As reported by the European Asphalt Pavement Association (EAPA), more than $90 \%$ of the roads in Europe are surfaced with asphalt mixtures. It means that about 950 billion tonnes of asphalt mixtures are incorporated in the European road network. Typically, properly designed and maintained asphalt pavements operate for ten to twenty-five years, after which they have to be rehabilitated. Asphalt mixtures are $100 \%$ recyclable. Therefore, construction and rehabilitation technologies with a strong focus on recycling and reuse have priority over all other methods.

Cold recycling technology rehabilitates asphalt pavement by recovering and reusing asphalt mixtures from distressed pavement without preheating. It results in less energy consumption and $\mathrm{CO}_{2}$ emission than other rehabilitation techniques (Cross et al., 2011; Thenoux et al., 2007). As a rule, distressed pavement is milled or broken, crushed to meet the required gradation of reclaimed asphalt pavement (RAP), rebound with either bituminous and hydraulic binders, or only with a hydraulic binder, laid down and compacted (Wood et al., 1988). The base course mainly is constructed from cold recycled asphalt mixture and contains up to $100 \%$ of RAP (Betti et al., 2016; Dal Ben \& Jenkins, 2014; Hugener et al., 2013; Stimilli et al., 2013). If RAP gradation is inappropriate, the natural aggregate is added.

Cold recycling is done in-place (cold in-place recycling (CIR)) or in central-plant (cold central-plant recycling (CCPR), also known as cold plant recycling or by cold in-plant recycling (CIPR)). Cold in-place recycling is less expensive and results in lower $\mathrm{CO}_{2}$ emission than CCPR because RAP is directly used to produce cold mixture without transportation to a central plant and recycled mixture from the central plant to the field (Giani et al., 2015). Consequently, CIR is preferable to CCPR. However, CCPR is more attractive if additional pavement layers before the cold recycled layer are required or different materials have to be accurately blended.

The performance of cold recycled asphalt mixture depends on the type of binding agents and the amount used and is significantly affected by the curing time and moisture content (Cardone et al., 2015; Graziani 
et al., 2016; Kim et al., 2011). Typically, a bituminous binder (foamed bitumen or bitumen emulsion) in combination with a hydraulic binder (Portland cement or lime) or only hydraulic binder is used to bind RAP with or without natural aggregate (Cross, 1999; Kearney, 1997; Wood et al., 1988). A blend of bituminous and hydraulic binder is used to enhance the mechanical properties of the cold recycled mixture, especially to quickly obtain the desired bearing capacity of the layer and to prevent shrinkage cracking (Bocci et al., 2011; Grilli et al., 2012; Li et al., 2016; Yan et al., 2017; Zaumanis \& Haritonovs, 2016). However, the amount of hydraulic binder is limited to avoid a decrease in the mixture flexibility, except if the only hydraulic binder is used.

Cold recycled mixtures bond with both bituminous and hydraulic binder are more resistant to permanent deformation, thermal cracking and moisture, and less susceptible to temperature (Babagoli et al., 2016; Iwański \& Chomicz-Kowalska, 2013; Leandri et al., 2015; Mueller et al., 2014; Niazi \& Jalili, 2009; Stimilli et al., 2013; Yan et al., 2017). However, they are weaker and more prone to fatigue (repeated loading) (Leandri et al., 2015; Mueller et al., 2014; Stimilli et al., 2013). The type of bituminous binder also influences the performance of cold recycled mixtures. Cold recycled mixtures with foamed bitumen have higher tensile strength than those with bitumen emulsion. Moreover, they have higher dynamic modulus and more significant flow numbers at the same moisture content (Kim et al., 2011). Iwański \& Chomicz-Kowalska (2011) concluded that foamed bitumen also ensures higher resistance to moisture and frost than bitumen emulsion. Notwithstanding these advantages, the usage of foamed bitumen results in a higher production cost of a cold recycled mixture since bitumen has to be preheated to reach the foaming temperature and special equipment has to be used for foam production.

Cold recycled mixtures bonded only with hydraulic binders are significantly stiffer than those bonded with a combination of bituminous and hydraulic binders and leads to significantly stronger pavement structure. The strength of cold recycled mixture with cement increases with increasing binder content, nature aggregate content, and curing time and decreases with increasing RAP content (Ji et al., 2016; Liu \& Wang, 2017). However, they tend to shrink due to loss of moisture and hydraulic binder hydration. In asphalt pavements, these cracks reflect through the asphalt concrete surface and lead to faster pavement deterioration.

Many researches on the performance of cold recycled mixtures has been done (Babagoli et al., 2016; Betti et al., 2016; Bocci et al., 2011; Dal Ben \& Jenkins, 2014; Iwański \& Chomicz-Kowalska, 2011, 2013; Leandri et al., 2015; Mueller et al., 2014; Niazi \& Jalili, 2009; Stimilli et 
al., 2013; Vaitkus et al., 2017; Yan et al., 2017). However, there is unclear how the performance of the entire pavement structure (cold recycled asphalt pavement overlaid with asphalt mixture) depends on the binding agent. Therefore, the main objective of this research is to evaluate the performance of cold in-place recycled asphalt pavement considering the types of binding agents (bituminous binder in combination with a hydraulic binder or only hydraulic binder) and figure out which binder leads to the best pavement performance.

\section{Experimental research}

\subsection{Cold in-place recycled road sections}

During the experimental research, three sections of road No. A16 Vilnius-Prienai-Marijampolé, from $34.460 \mathrm{~km}$ to $35.300 \mathrm{~km}$, from $35.300 \mathrm{~km}$ to $38.800 \mathrm{~km}$, and from $41.200 \mathrm{~km}$ to $57.300 \mathrm{~km}$ (in total $20.440 \mathrm{~km}$ ) were analysed. The pavement of these road sections was rehabilitated using CIR in 2000-2005 (Table 1). In two road sections (from $34.460 \mathrm{~km}$ to $35.300 \mathrm{~km}$ and from $41.200 \mathrm{~km}$ to $57.300 \mathrm{~km}$ ), RAP was bound with both foamed bitumen and Portland cement, while in the remaining road section, only Portland cement was used. An annual average daily traffic (AADT, vpd) on road No. A16 Vilnius-PrienaiMarijampole from $34.460 \mathrm{~km}$ to $57.300 \mathrm{~km}$ during 2000-2017 is given in Figure 1. Different pavement structures were used in each road section since AADT in the rehabilitation (construction) year, and the thickness of the cold recycled layer and the binding agents were different. The thickness of the entire newly constructed pavement structure varied from $25 \mathrm{~cm}$ to $31 \mathrm{~cm}$ (Table 2).

Table 1. Analysed cold in-place recycled road No. A16 Vilnius-Prienai-Marijampolè

\begin{tabular}{ccccc}
\hline \multicolumn{2}{c}{ Road section, km } & $\begin{array}{c}\text { Section } \\
\text { length, km }\end{array}$ & $\begin{array}{c}\text { Rehabilitation } \\
\text { (construction) } \\
\text { year }\end{array}$ & Binder \\
\hline 34.460 & 35.300 & 0.840 & 2000 & $\begin{array}{c}\text { Foamed bitumen + } \\
\text { Portland cement }\end{array}$ \\
\hline 35.300 & 38.800 & 3.500 & 2003 & Portland cement \\
\hline 41.200 & 57.300 & 16.100 & 2005 & $\begin{array}{c}\text { Foamed bitumen + } \\
\text { Portland cement }\end{array}$ \\
\hline
\end{tabular}

Note: Average Annual Daily Traffic is for two directions.
Audrius Vaitkus, Judita Gražulytė, Andrius Baltrušaitis, Jurgita Židanavičiūtè, Donatas Čygas

Long-Term Performance of Pavement Structures with Cold in-Place Recycled Base Course 


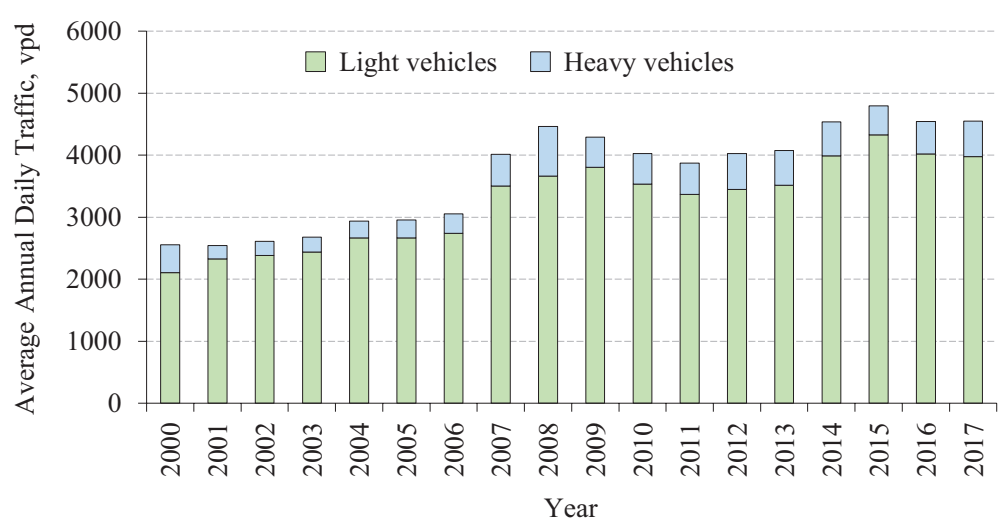

Figure 1. Average Annual Daily Traffic on the road No. A16 from 2000 to 2017

Table 2. Newly constructed pavement structures in road No. A16 Vilnius-Prienai-Marijampolè

\begin{tabular}{|c|c|c|c|c|c|c|}
\hline \multicolumn{2}{|c|}{ Road section, km } & \multirow{3}{*}{$\begin{array}{l}\text { Cold } \\
\text { recycled } \\
\text { layer, } \\
\mathrm{cm}\end{array}$} & \multicolumn{3}{|c|}{ Thickness, cm } & \multirow{3}{*}{ Total } \\
\hline \multirow{2}{*}{ beginning } & \multirow{2}{*}{ end } & & \multicolumn{3}{|c|}{ Asphalt } & \\
\hline & & & base course & binder course & wearing course & \\
\hline 34.460 & 35.300 & 20 & - & - & 5 & 25 \\
\hline 35.300 & 38.800 & 18 & - & 6 & $2.5\left(4^{1)}\right)$ & $26.5\left(30.5^{2)}\right)$ \\
\hline 41.200 & 57.300 & 16 & 6 & 5 & 4 & 31 \\
\hline
\end{tabular}

\subsection{Methodology}

The performance of the entire pavement structure (cold recycled asphalt pavement overlaid with asphalt mixtures) was assessed in 2013 and 2017 based on the:

- International Roughness Index (IRI);

- rut depth;

- pavement surface distress.

All this information was collected with the help of Mobile Road Survey Laboratory RST 28, which consists of:

- a gyroscope, which measures longitudinal and crosswise road pavement profile;

- laser meters, which measure longitudinal and crosswise road micro-profile (laser profilograph); 
Table 3. Measurements on the road No. A16 Vilnius-Prienai-Marijampolè

\begin{tabular}{|c|c|c|c|c|c|c|}
\hline \multicolumn{2}{|c|}{ Road section, km } & \multirow{2}{*}{$\begin{array}{l}\text { Section } \\
\text { length, } \\
\text { km }\end{array}$} & \multirow[t]{2}{*}{ Direction } & \multirow{2}{*}{$\begin{array}{c}\text { Road } \\
\text { section } \\
\text { index }\end{array}$} & \multicolumn{2}{|c|}{$\begin{array}{c}\text { Number } \\
\text { of measurements }\end{array}$} \\
\hline beginning & end & & & & in 2013 & in 2017 \\
\hline \multirow{2}{*}{34.460} & \multirow{2}{*}{35.300} & \multirow{2}{*}{0.840} & Left & L1 & 44 & 42 \\
\hline & & & Right & $\mathrm{R} 1$ & 44 & 42 \\
\hline \multirow{2}{*}{35.300} & \multirow{2}{*}{38.800} & \multirow{2}{*}{3.500} & Left & L2 & 176 & 174 \\
\hline & & & Right & $\mathrm{R} 2$ & 175 & 175 \\
\hline \multirow{2}{*}{41.200} & \multirow{2}{*}{57.300} & \multirow{2}{*}{16.100} & Left & L3 & 806 & 805 \\
\hline & & & Right & R3 & 798 & 805 \\
\hline
\end{tabular}

- a distance sensor;

- a camera, which takes photos of pavement surface;

- accelerometers, which isolate internal vibrations of measuring equipment affecting the indicators of laser meters;

- a processor, which processes data from all sensors;

- a Global Positioning System (GPS), which gives GPS coordinates and enables determination of a linear distance from the road beginning;

- a computer, which controls the work of the processor and stores data.

The Road and Transport Research Institute did all measurements. The data were given per each $20 \mathrm{~m}$ of the road section. The exact number of measurements (2043) was collected in 2013 and 2017 (Table 3). Descriptive statistics were used to analyse the collected data. IRI and rut depth were analysed according to the direction and left, and right wheel paths calculating mean, standard deviation (Std), minimum value, maximum value and quantiles of $25 \%$ and $75 \%$. A box-and-whiskers plot was used to depict data through quartiles graphically. The ends of the whiskers represented the minimum and maximum values. Each road section was indexed by section number and roadside (L1, R1, L2, and R2).

\section{Results}

\subsection{International Roughness Index}

Measured IRI in left and right wheel paths on the road No. A16 Vilnius-Prienai-Marijampole in 2013 and 2017 is graphically depicted in the box-and-whisker plots (Figure 2). Figure 3 presents the mean IRI and

\section{Donatas Cygas}

Long-Term

Performance

of Pavement

Structures with Cold

in-Place Recycled

Base Course 


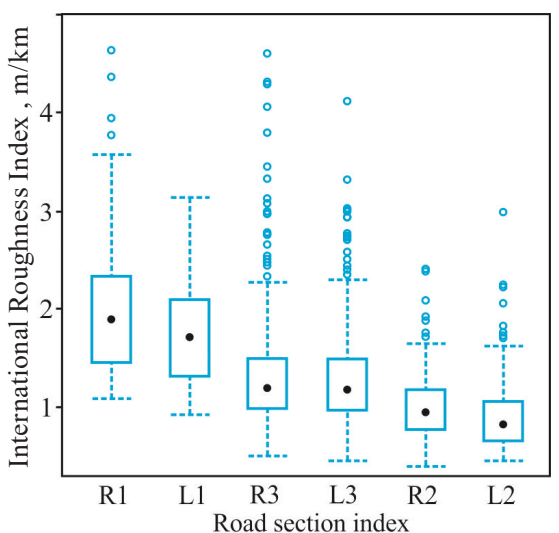

a) in left wheel path in 2013

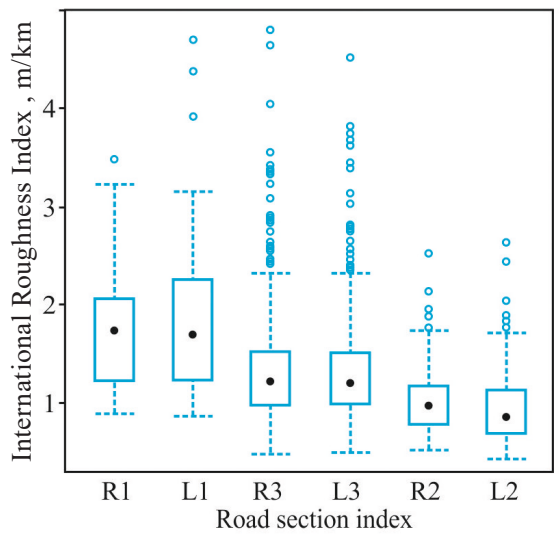

c) in left wheel path in 2017

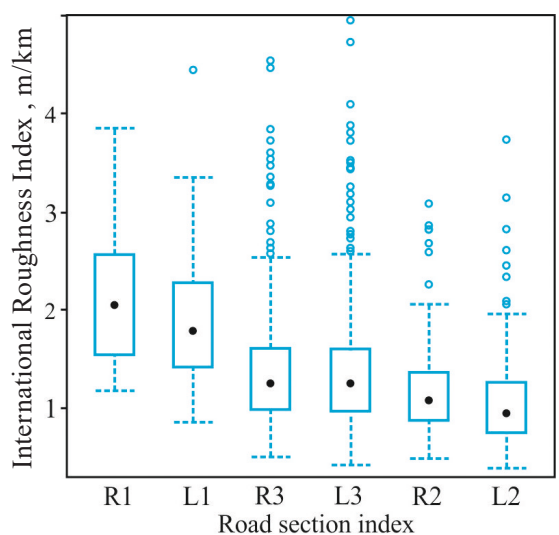

b) in right wheel path in 2013

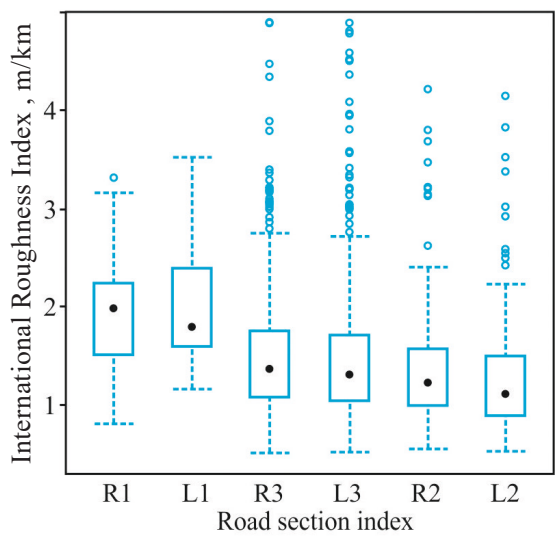

d) in right wheel path in 2017

Figure 2. International Roughness Index

its standard deviation in the left and right wheel paths, as well as the IRI critical limit of $1.5 \mathrm{~m} / \mathrm{km}$. Road section from $35.300 \mathrm{~km}$ to $38.800 \mathrm{~km}$, in which RAP was bound with cement in 2003 (L2 and R2), showed the best performance according to IRI in both 2013 and 2017. In 2013 in this section, the mean of IRI was $0.896 \mathrm{~m} / \mathrm{km}$ (L2) and $1.003 \mathrm{~m} / \mathrm{km}$ (R2) in the left wheel path and $1.074 \mathrm{~m} / \mathrm{km}$ (L2) and $1.181 \mathrm{~m} / \mathrm{km}$ (R2) in the right wheel path. In 2017 the mean of IRI in the left wheel path was almost the same (0.945 m/km (L2) and 1.012 (R2)) as in 2013; however, in the right wheel path, it increased by $14.1-15.5 \%$.

The age difference of five years between the road sections in which RAP was bound with foamed bitumen and cement led to 1.31.5 times higher mean of IRI in both 2013 and 2017. Comparing to the measurements in 2013, in 2017, the mean of IRI on those road sections 


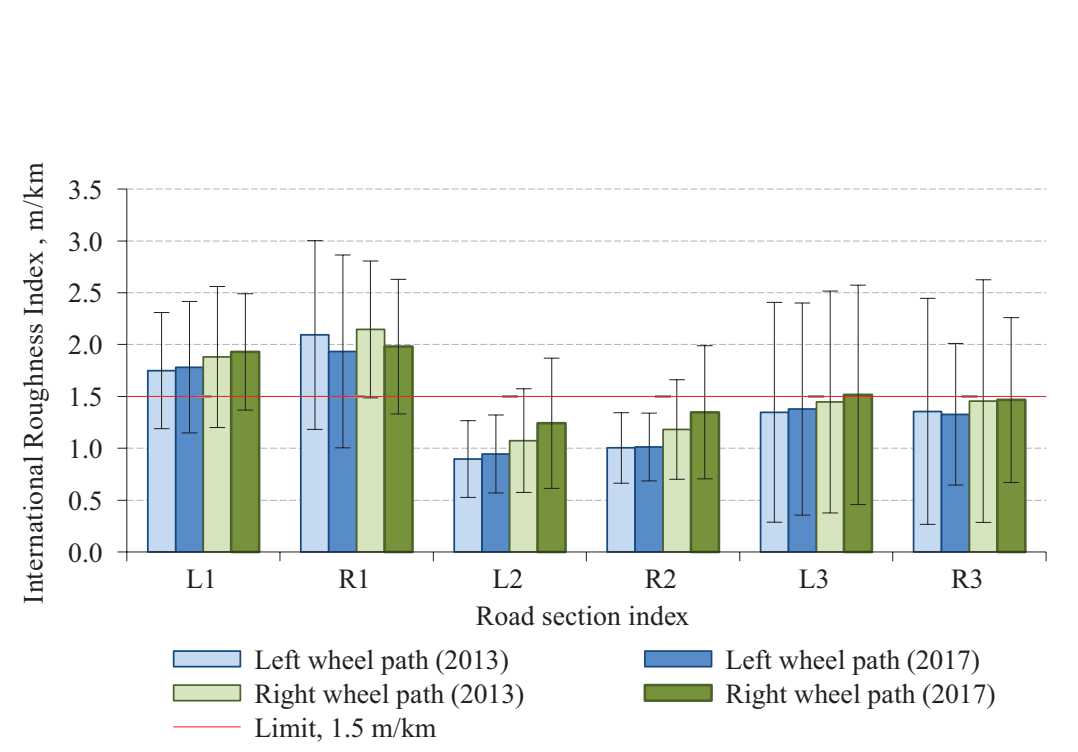

Audrius Vaitkus, Judita Gražulytė, Andrius Baltrušaitis, Jurgita Židanavičiūtè, Donatas Čygas

Long-Term

Performance

of Pavement

Structures with Cold in-Place Recycled Base Course

Figure 3. Mean of International Roughness Index in 2013 and 2017

changed by $0.01-0.17 \mathrm{~m} / \mathrm{km}$. In most cases, IRI increased, but on the first road section in both wheel paths of the right direction (R1) and on the third road section in the left wheel path of the right direction (R3), the mean of IRI decreased by $2.1-7.7 \%$. This decrease in the mean of IRI was caused by the periodical repair works done and the measurement errors.

In Lithuania, IRI on main roads has to be below $1.5 \mathrm{~m} / \mathrm{km}$. On all analysed road sections, some individual values no less than $1.5 \mathrm{~m} / \mathrm{km}$ were found. However, the mean of IRI above $1.5 \mathrm{~m} / \mathrm{km}$ was determined only on the oldest road section, which was rehabilitated in 2000 (L1 and R1 in both 2013 and 2017). The newest road section, which was rehabilitated in 2005, also had the mean of IRI above $1.5 \mathrm{~m} / \mathrm{km}$, but only on the right wheel path of the left direction (L3).

In all cases, IRI in the left wheel path was lower than in the right wheel path, regardless of the rehabilitation year, direction, and binding agent. A geometry of road cross-section, especially the slope, leading to it. Besides, IRI in the left direction, except for the third road section in 2017, was lower than in the right direction regardless of the rehabilitation year and binding agent. A different AADT in each direction was a possible reason for this.

Since all road sections were constructed in different years (2000, 2003, and 2005), what led to different pavement age at the time of measured IRI (2013 and 2017), the collected data were rearranged so that the pavement age is almost the same. For this purpose, the mean of IRI measured in 2013 for the first road section (L1 and R1) and in 2017 for the second and third road sections (L2, R2, L3, and R3) is given in Figure 4. It resulted in a pavement age of 13, 14 and 12 years. 


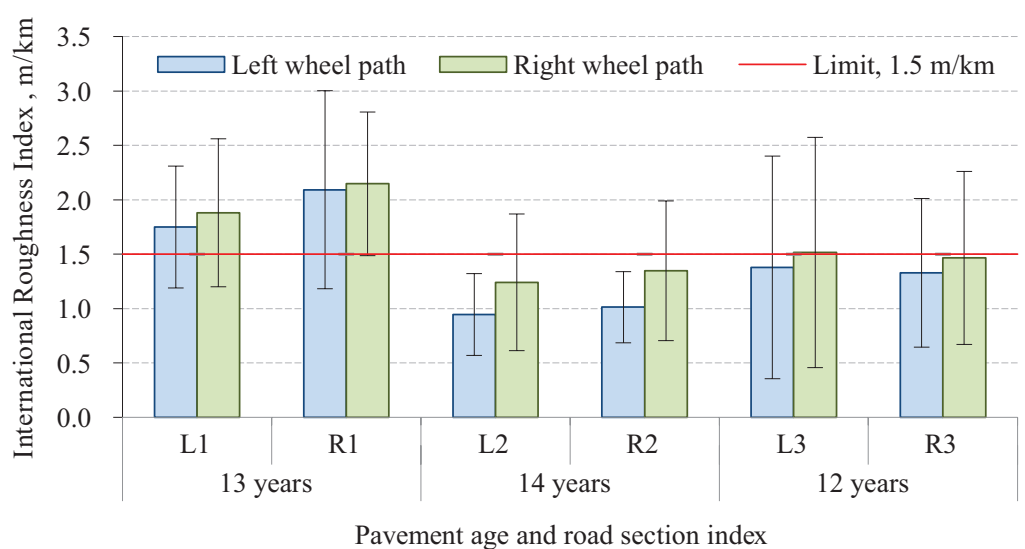

Figure 4. Mean of International Roughness Index by pavement age

The rearranged data confirms that road section from $35.300 \mathrm{~km}$ to $38.800 \mathrm{~km}$, in which RAP was bound with cement (L2 and R2) performs the best and, even after 14 years, meets the requirement for IRI (no more than $1.5 \mathrm{~m} / \mathrm{km}$ ). Meanwhile, the worst performance was revealed by the road section from $34.460 \mathrm{~km}$ to $35.300 \mathrm{~km}$, in which RAP was bound with both foamed bitumen and cement (L1 and R1). A too-thin pavement is a possible reason for a failure to pass the requirement for IRI since only asphalt wearing course in thickness of $5 \mathrm{~cm}$ was laid on the cold recycled base course (total pavement thickness - $25 \mathrm{~cm}$ ). Besides, the road section from $41.200 \mathrm{~km}$ to $57.300 \mathrm{~km}$, in which RAP was also bound with foamed bitumen and cement (L3 and R3), but much thicker asphalt layers were laid on the cold recycled base course (total pavement thickness $-31 \mathrm{~cm}$ ) met the requirement.

\subsection{Rut depth}

Measured rut depths in the left and right wheel paths on the road No. A16 Vilnius-Prienai-Marijampole in 2013 and 2017 are graphically depicted in the box-and-whisker plots (Figure 5). Figure 6 presents the mean of rut depth and its standard deviation in left and right wheel paths. In 2013, the second road section, in which RAP was bound with cement in 2003, showed the best performance (no more than $2.14 \mathrm{~mm}$ ) except for the right wheel path in the right direction. There the mean of rut depth was $3.04 \mathrm{~mm}$. Meanwhile, on-road sections bound with both foamed bitumen and cement, the mean of rut depth varied from $2.36 \mathrm{~mm}$ (left wheel path of right direction (R1)) to $4.56 \mathrm{~mm}$ (right wheel path of right direction (R3)). 


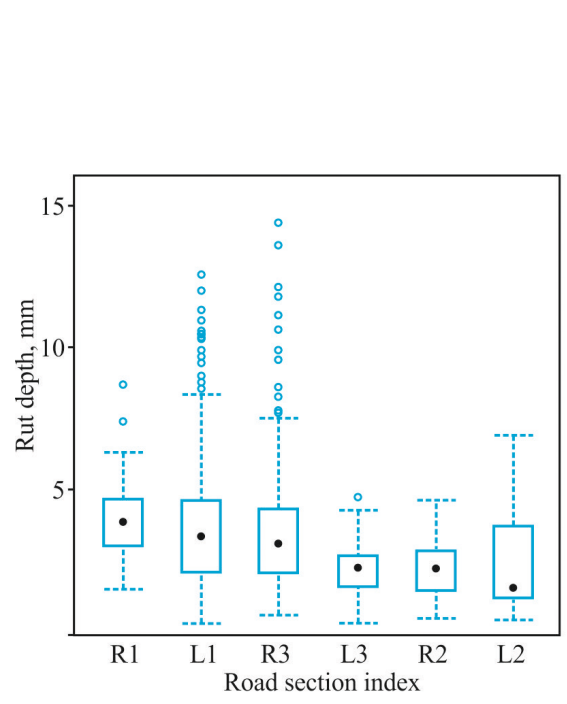

a) in left wheel path in 2013

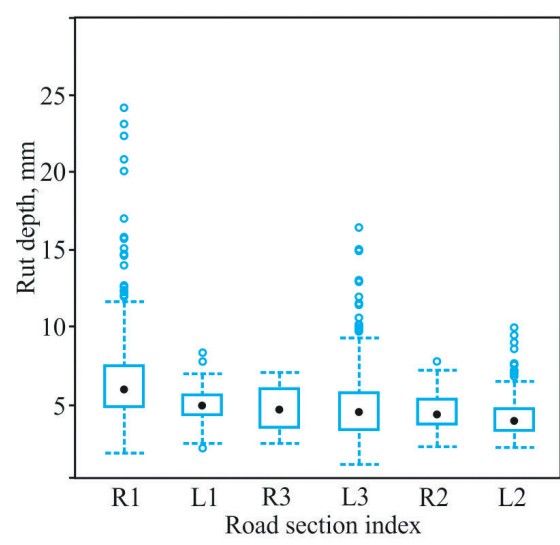

c) in left wheel path in 2017

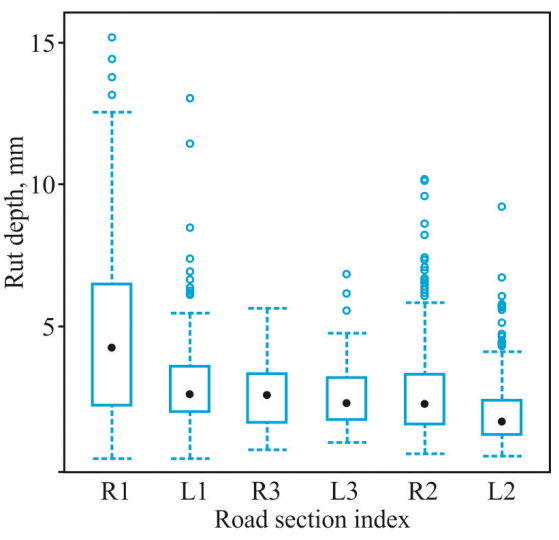

b) in right wheel path in 2013

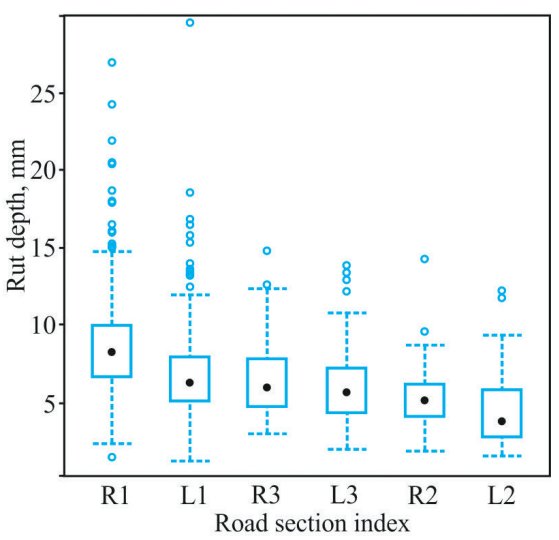

d) in right wheel path in 2017
Audrius Vaitkus, Judita Gražulytė, Andrius Baltrušaitis, Jurgita Židanavičiūtè, Donatas Čygas

Long-Term

Performance

of Pavement

Structures with Cold in-Place Recycled Base Course

Figure 5. Rut depth

Comparing to the measurements in 2013, in 2017, the mean of rut depth increased by 1.3-2.8 times and varied from $4.15 \mathrm{~mm}$ (left wheel path of left direction (L2)) to $8.38 \mathrm{~mm}$ (right wheel path of right direction (R3)). The highest increase in rut depth irrespective of wheel path and direction was determined for the second road section, in which RAP was bound with cement in 2003 (L2 and R2). Thus, during 2013-2017, the deterioration of this pavement structure in rutting was the fastest. Meanwhile, road sections, in which RAP was bound with both foamed bitumen and cement, deteriorated quite similar to each other (the difference was up to 17\%) except in the right wheel path of left direction. The third road section during 2013-2017 deteriorated about $40 \%$ faster than the first road section. 


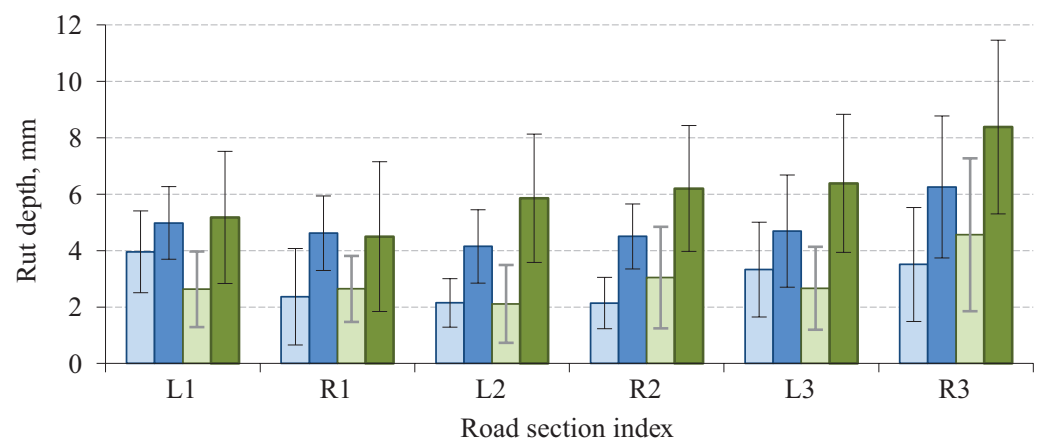

Left wheel path (2013)

Right wheel path (2013)

Left wheel path (2017)

Right wheel path (2017)

Figure 6. Mean of rut depth in 2013 and 2017

In all cases (except L1, L2 and L3 in 2013, and R1 in 2017), rut depth in the left wheel path is smaller than in the right wheel path. A geometry of road cross-section, especially the slope, leading to it. The statistical analysis showed that the correlation between rut depth and wheel path, direction, or road rehabilitation year is non-existent.

In Lithuania, on main roads, the rut depth has to be below $15 \mathrm{~mm}$. All analysed road sections satisfied this requirement since all measured values were bellow $12 \mathrm{~mm}$, even after seventeen years of operation (L1 and R1).

Since all road sections were constructed in different years (2000, 2003, and 2005), what led to different pavement age at the time of measured rut depth (2013 and 2017), the collected data were rearranged. For this purpose, Figure 7 gives the mean of rut depth

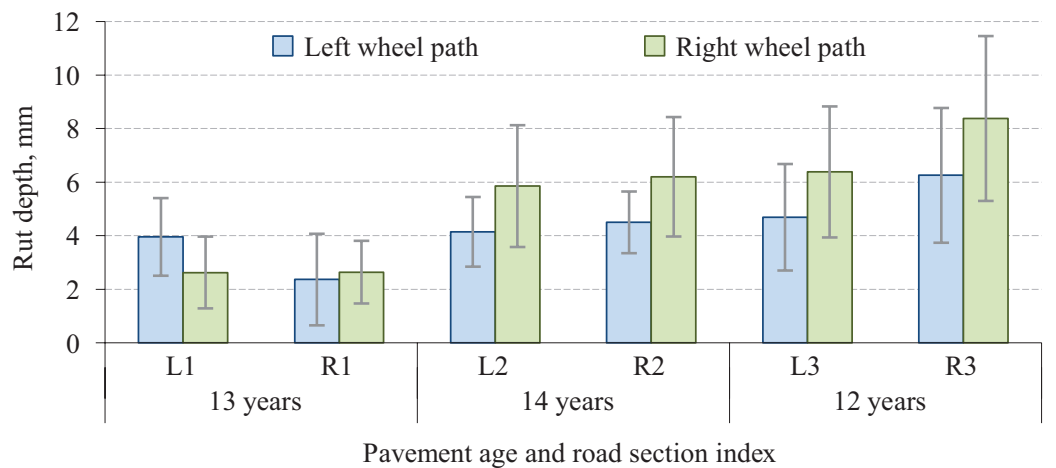

Figure 7. Mean of rut depth by pavement age 
measured in 2013 for the first road section (L1 and R1) and in 2017 for the second and third road sections (L2, R2, L3, and R3). It resulted in a pavement age of 13,14 , and 12 years. The rearranged data shows that road section from $34.600 \mathrm{~km}$ to $35.300 \mathrm{~km}$, in which RAP was bound with both foamed bitumen and cement (L1 and R1), performs the best. Meanwhile, the worst performance was revealed by the road section from $41.200 \mathrm{~km}$ to $57.300 \mathrm{~km}$. Here RAP was also bound with both foamed bitumen and cement (L3 and R3). This finding was unexpected since the thickness of asphalt layers in the first road section (L1 and R1) is much thinner than in the third road section (the difference is up to $10 \mathrm{~cm}$ ). A possible explanation for this kind of performance is that rut depth after pavement construction in the third road section was much deeper than in the first road section. Unfortunately, data regarding the rut depth after the construction of road sections is missing.

\subsection{Pavement surface distress}

In 2017, on the analysed road sections of road No. A16 VilniusPrienai-Marijampole transverse cracks, longitudinal cracks, fatigue cracks, asphalt patches, and bleeding and tracking were observed (Figure 8). The severity of each distress is given in Figure 9.

On the road section from $34.460 \mathrm{~km}$ to $35.300 \mathrm{~km}$, which was cold recycled in 2000 using foamed bitumen and cement, transverse cracks and patches were dominant. Additionally, some areas were subjected to bleeding, and some longitudinal cracks (below 1\%) have appearedalmost all longitudinal cracks formed at the centre line of the road. There a longitudinal joint was constructed. Although it was the oldest pavement, fatigue cracking was not observed. The total amount of distressed pavement in 2017 was $2.197 \%$ and $3.943 \%$ in the right and left directions, respectively.

The road section from $41.200 \mathrm{~km}$ to $57.300 \mathrm{~km}$, which was rehabilitated in 2005 using foamed bitumen and cement, showed the best performance. The total amount of distressed pavement in 2017 was only $0.514 \%$ and $0.652 \%$ in the right and left directions, respectively. It was influenced by lower pavement age compared to the road section from $34.460 \mathrm{~km}$ to $35.300 \mathrm{~km}$. In the right direction, slight bleeding was observed as well as in the first section. It is a consequence of using an overly high binder content in asphalt mixture.

The road section from $35.300 \mathrm{~km}$ to $38.800 \mathrm{~km}$, which was cold recycled in 2003 using only cement, performed the worst. The total amount of distressed pavement in 2017 was $5.923 \%$ and $7.016 \%$ in the right and left directions, respectively. In this section, transverse cracks were the most significant distress. They occurred because of the cold 


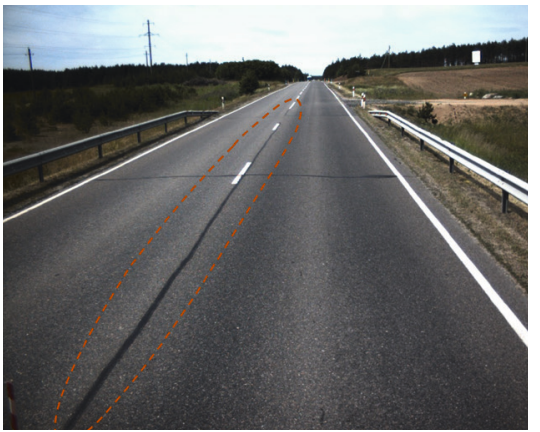

Longitudinal crack (R2, cement, 2003)

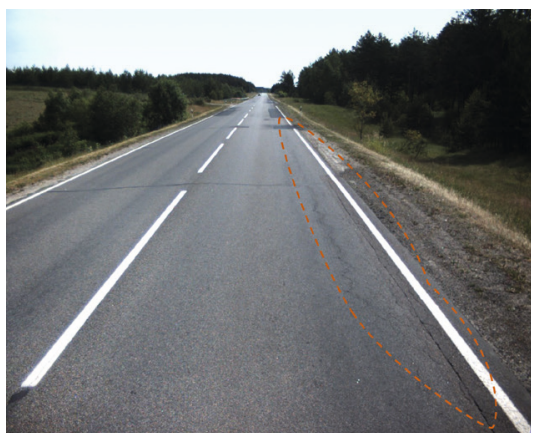

Fatigue crack

(L2, cement, 2003)

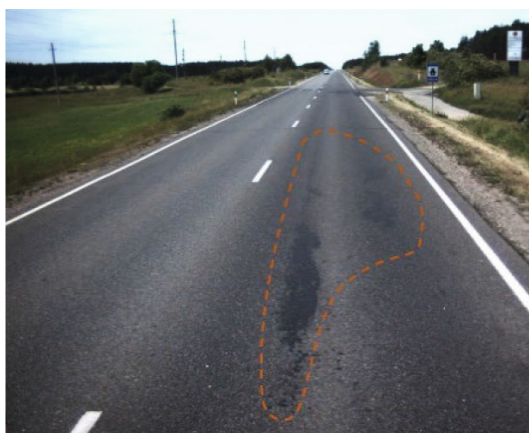

Bleeding

(R1, foamed bitumen + cement, 2000)

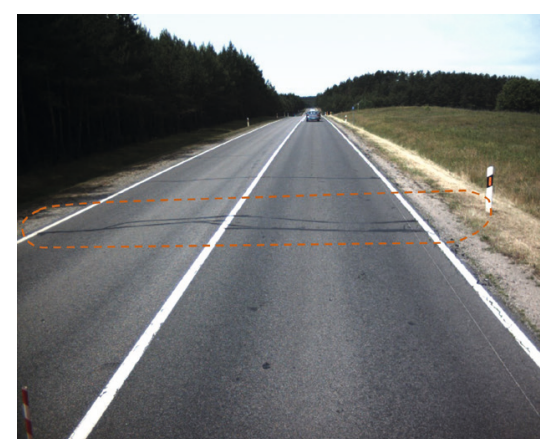

Transverse crack (R2, cement, 2003)

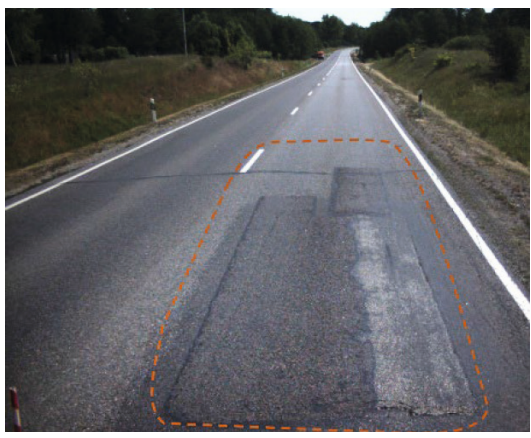

Asphalt patches

(L1, foamed bitumen+cement, 2000)

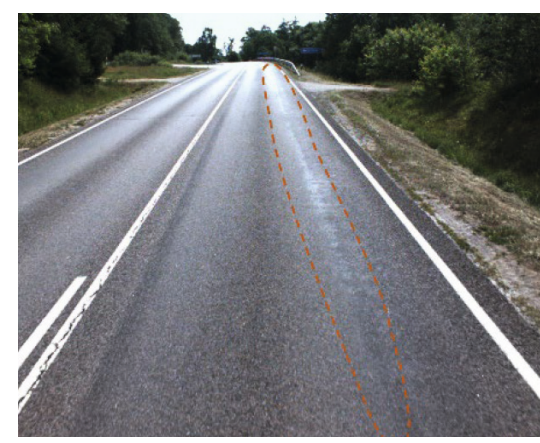

Tracking

(L3, foamed bitumen+cement, 2005)

Note: section index, binding agents and rehabilitation year are given in brackets.

Figure 6. Pavement surface distress observed on analysed road sections 


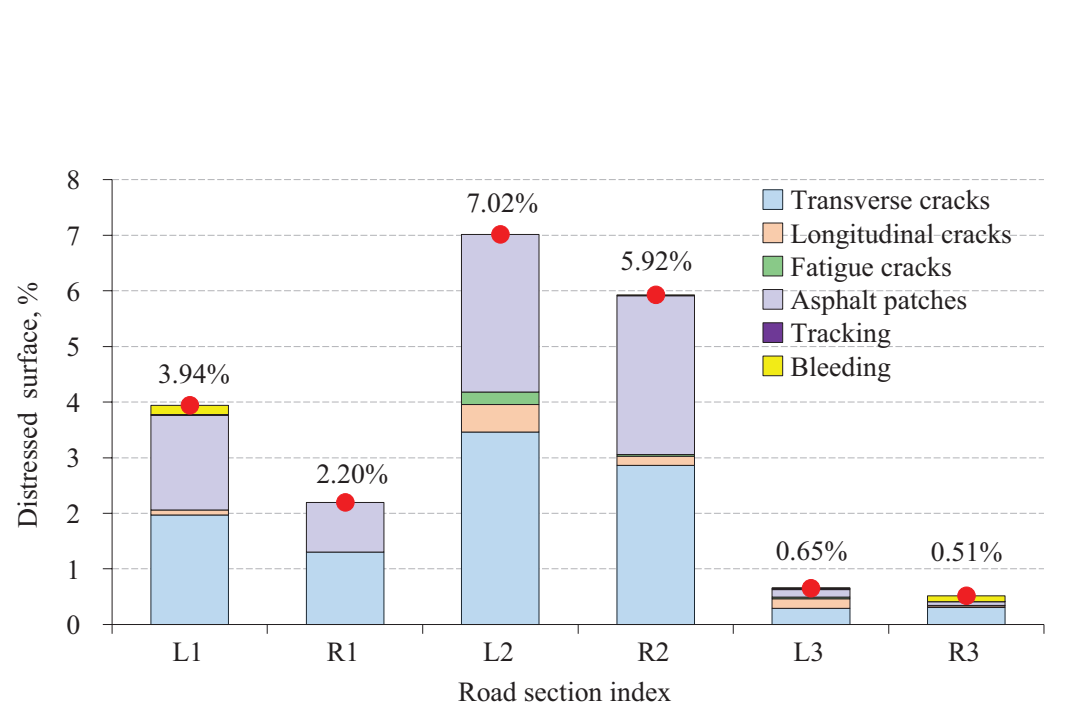

Figure 7. Pavement distress in 2017

recycled layer cracking since hydraulically bound materials tend to crack at low temperatures. There also are dominant patches (2.833\%), and longitudinal and fatigue cracks have also appeared. Failure of the cold recycled layer under repeated traffic loading is a possible cause of fatigue cracks. Most of the longitudinal cracks appeared at the centre line of the road, where a longitudinal joint was constructed.

\section{Conclusions}

From the performance analysis of three cold in-place recycled asphalt pavements (in 2000, 2003, and 2005) considering the types of binding agents (bituminous binder in combination with a hydraulic binder or only hydraulic binder), the following conclusions are drawn:

1. From the IRI point of view, pavement structure (total thickness of recycled pavement structure $-30.5 \mathrm{~cm}$ ) composed of two asphalt layers laid on cold in-place recycled base course (binder - cement) performs the best despite its high deterioration during 2013-2017 and susceptibility to cracking, especially to transverse cracking (2.862\% and $3.461 \%$ in the right and left directions, respectively). There, the mean of IRI after 14 years of operation was $0.945 \mathrm{~m} / \mathrm{km}$ (L2) and $1.012 \mathrm{~m} / \mathrm{km}(\mathrm{R} 2)$ in the left wheel path and $1.242 \mathrm{~m} / \mathrm{km}$ (L2) and $1.347 \mathrm{~m} / \mathrm{km}$ (R2) in the right wheel path.

2. Pavement structure (total thickness of recycled pavement structure $-25 \mathrm{~cm}$ ) composed of one asphalt layer laid on cold in-place recycled base course (binder - foamed bitumen+cement) fails to meet the requirement for IRI (no more than $1.5 \mathrm{~m} / \mathrm{km}$ )
Audrius Vaitkus, Judita Gražulytė, Andrius Baltrušaitis, Jurgita Židanavičiūtè, Donatas Čygas

Long-Term

Performance

of Pavement

Structures with Cold in-Place Recycled Base Course 
because of the too-thin asphalt layer. The increase in thickness of recycled pavement structure up to $31 \mathrm{~cm}$ led to the required IRI even after 12 years of operation. However, this pavement structure had the highest rutting (4.7 $\mathrm{mm}$ (L3) and $6.3 \mathrm{~mm}$ (R3) in the left wheel path and $6.4 \mathrm{~mm}$ (L3) and $8.4 \mathrm{~mm}$ (R3) in the right wheel path). The possible explanation for this kind of performance is related to the inhomogeneity of pavement structure layers.

3. Regarding the rut depth in 2013 and 2017 , some anomaly occurred with differences between the right and left wheel paths since the left wheel path rutting was bigger than the right one, or vice versa depending on traffic direction and road section. It is be related to inhomogeneous properties of asphalt layers and cold in-place recycled base course. The same inhomogeneity indicated rutting differences among traffic directions.

4. From the distressed pavement area point of view, pavement structure with cement bound base layer performs the worst among three sections. The amount of distressed pavement area after 14 years of operation was $5.923 \%$ and $7.016 \%$ in the right and left directions, respectively. There dominant transverse cracks $(2.862 \%$ and $3.461 \%$ in the right and left directions, respectively) and patches (2.833\%). Transverse cracks reflect cracks in the hydraulically bound layer, which tend to crack at low temperatures.

5. It is under discussion what binder (foamed bitumen+cement or only cement) ensures the best cold in-place recycled pavement performance since the analysed road sections performed differently in terms of RI, rut depth and pavement distress. Furthermore, the analysed road sections differ from each other with pavement structure composition, rehabilitation year, and the cold recycled layer thickness. Thus, it complicates the evaluation of binder influence on the performance of cold in-place recycled pavement. Nevertheless, pavement structure with cement bound base layer ensures the evenness of pavement surface and seems like a promising solution. However, there is a need to find a way to minimise low temperature cracking (e.g., to use a stress absorbing membrane interlayer).

\section{Funding}

This research project is financially supported by a grant from the Lithuanian Road Administration under the Ministry of Communications. 


\section{Disclosure Statement}

The authors reported no potential conflict of interest.
Audrius Vaitkus, Judita Gražulytė, Andrius Baltrušaitis, Jurgita Židanavičiūtè, Donatas Čygas

Long-Term Performance of Pavement Structures with Cold in-Place Recycled Base Course

\section{REFERENCES}

Babagoli, R, Ameli, A., \& Shahriari, H. (2016). Laboratory evaluation of rutting performance of cold recycling asphalt mixtures containing SBS modified asphalt emulsion, Petroleum Science \& Technology 34(4), 309-313. https://doi.org/10.1080/10916466.2015.1135168

Betti, G., Airey, G., Jenkins, K., Marradi, A., \& Tebaldi, G. (2016). Active filler's effect on in situ performances of bitumen emulsion recycled mixtures. In 8 th RILEM International Symposium on Testing \& Characterization of Sustainable \& Innovative Bituminous Materials (pp. 799-810). Springer, Dordrecht. https://doi.org/10.1007/978-94-017-7342-3_64

Bocci, M., Grilli, A., Cardone, F., \& Graziani, A. (2011). A study on the mechanical behaviour of cemen-bitumen treated materials, Construction \& Building Materials 25(2), 773-778. https://doi.org/10.1016/j.conbuildmat.2010.07.007

Cardone, F., Grilli, A., Bocci, M., \& Graziani, A. (2015). Curing and temperature sensitivity of cement-bitumen treated materials, International Journal of Pavement Engineering 16(10), 868-880. https://doi.org/10.1080/10298436.2014.966710

Cross, S. (1999). Experimental cold in-place recycling with hydrated lime Transportation Research Board 1684(1), 186-193. https://doi.org/10.3141/1684-22

Cross, S., Chesner, W., Justus, H., \& Kearney, E. (2011). Life-cycle environmental analysis for evaluation of pavement rehabilitation options, Transportation Research Board 2227(516), 43-52. https://doi.org/10.3141/2227-05

Dal Ben, M., \& Jenkins, K. J. (2014). Performance of cold recycling materials with foamed bitumen and increasing percentage of reclaimed asphalt pavement, Road Materials \& Pavement Design 15(2), 348-371. https://doi.org/10.1080/14680629.2013.872051

Giani, M. I., Dotelli, G., Brandini, N., \& Zampori, L. (2015). Comparative life cycle assessment of asphalt pavements using reclaimed asphalt, warm mix technology and cold in-place recycling, Resources, Conservation \& Recycling 104, 224-238. https://doi.org/10.1016/j.resconrec.2015.08.006

Graziani, A., Godenzoni, C., Cardone, F., \& Bocci, M. (2016). Effect of curing on the physical and mechanical properties of cold-recycled bituminous mixtures, Materials \& Design 95, 358-369. https://doi.org/10.1016/j.matdes.2016.01.094

Grilli, A., Graziani, A., \& Bocci, M. (2012). Compactability and thermal sensitivity of cement-bitumen-treated materials, Road Materials \& Pavement Design 13(4): 599-617. https://doi.org/10.1080/14680629.2012.742624 
Hugener, M., Partl, M. N., \& Morant, M. (2013). Cold asphalt recycling with $100 \%$ reclaimed asphalt pavement and vegetable oil-based rejuvenators, Road Materials \& Pavement Design 15(2), 239-258. https://doi.org/10.1080/14680629.2013.860910

Iwanski, M., \& Chomicz-Kowalska, A. (2011). The effects of using foamed bitumen and bitumen emulsion in the cold recycling technology. In Environmental Engineering. Proceedings of the International Conference on Environmental Engineering. ICEE (Vol. 8, p. 1089). Vilnius Gediminas Technical University, Department of Construction Economics \& Property.

Iwański, M., \& Chomicz-Kowalska, A. (2013). Laboratory study on mechanical parameters of foamed bitumen mixtures in the cold recycling technology, Procedia Engineering 57, 433-442. https://doi.org/10.1016/j.proeng.2013.04.056

Ji, X., Jiang, Y., \& Liu, Y. (2016). Evaluation of the mechanical behaviors of cement-stabilised cold recycled mixtures produced by vertical vibration compaction method, Materials \& Structures 49(6), 2257-2270. https://doi.org/10.1617/s11527-015-0647-x

Kearney, E. (1997). Cold mix recycling: state-of-the-practice, Journal of the Association of Asphalt Paving Technologists 66, 760-784.

Kim, Y., Im, S., \& Lee, H. D. (2011). Impacts of curing time and moisture content on engineering properties of cold in-place recycling mixtures using foamed or emulsified asphalt, Journal of Materials in Civil Engineering 23(5), 542-553. https://doi.org/10.1061/(ASCE)MT.1943-5533.0000209

Leandri, P., Losa, M., \& Di Natale, A. (2015). Field validation of recycled cold mixes viscoelastic properties, Construction \& Building Materials 75, 275-282. https://doi.org/10.1016/j.conbuildmat.2014.11.028

Li, Z., Hao, P., Liu, H., Xu, J., \& Chen, Z. (2016). Investigation of early-stage strength for cold recycled asphalt mixture using foamed asphalt, Construction \& Building Materials 127, 410-417. https://doi.org/10.1016/j.conbuildmat.2016.09.126

Liu, Y., \& Wang, Y. (2017). Study on mechanical properties of cement cold recycling mixtures in seasonally frozen soil region. DEStech Transactions on Engineering \& Technology Research (ictim), 972-981. https://doi.org/10.12783/dtetr/ictim2016/5591

Mueller, M., Singh, A. K., \& Lee, K. W. (2014). Cold In-place Recycling for Sustainable Streets and Highways (No. 14-3121).

Niazi, Y., \& Jalili, M. (2009). Effect of portland cement and lime additives on properties of cold in-place recycled mixtures with asphalt emulsion, Construction \& Building Materials 23(3), 1338-1343. https://doi.org/10.1016/j.conbuildmat.2008.07.020

Stimilli, A., Ferrotti, G., Graziani, A., \& Canestrari, F. (2013). Performance evaluation of a cold-recycled mixture containing high percentage of reclaimed asphalt, Road Materials \& Pavement Design 14 (sup1), 149-161. https://doi.org/10.1080/14680629.2013.774752 
Thenoux, G., González, Á., \& Dowling, R. (2007). Energy consumption Jurgita Židanavičiūtè, Donatas Čygas comparison for different asphalt pavements rehabilitation techniques used in Chile, Resources, Conservation \& Recycling 49(4), 325-339. https://doi.org/10.1016/j.resconrec.2006.02.005

Vaitkus, A., Gražulytė, J., Juknevičiūtė-Žilinskienė, L., \& Andrejevas, V. (2017). Review of Lithuanian experience in asphalt pavements cold recycling. Long-Term Performance of Pavement Structures with Cold in-Place Recycled Base Course In Environmental Engineering. Proceedings of the International Conference on Environmental Engineering. ICEE (Vol. 10, pp. 1-8). Vilnius Gediminas Technical University, Department of Construction Economics \& Property. https://doi.org/10.3846/enviro.2017.153

Wood, L. E., White, T. D., \& Nelson, T. B. (1988). Current practice of cold in-place recycling of asphalt pavements, Transportation Research Record 1178, 31-37.

Yan, J., Leng, Z., Li, F., Zhu, H., \& Bao, S. (2017). Early-age strength and long-term performance of asphalt emulsion cold recycled mixes with various cement contents, Construction \& Building Materials 137: 153-159. https://doi.org/10.1016/j.conbuildmat.2017.01.114

Zaumanis, M., \& Haritonovs, V. (2016). Long term monitoring of full scale pavement test section with eight different asphalt wearing courses. Materials \& Structures 49(5), 1817-1828. https://doi.org/10.1617/s11527-015-0614-6 